\title{
Effect of Absorbed Water on Space Charge Properties of Polyimide
}

\author{
Kazue Kaneko Member (Nagoya University, kaneko@nuee.nagoya-u.ac.jp) \\ Takashi Ozaki Non-member (Nagoya University) \\ Emi Nakane Student Member (Nagoya University) \\ Yasuo Suzuoki Member (Nagoya University) \\ Teruyoshi Mizutani Member (Aichi Institure of Techonology)
}

Keywords : space charge, polyimide, high-temperature polymer, water content, conduction current

\section{Introduction}

Polyimide (PI) is widely used as a high-temperature insulating material because of its good insulating, mechanical and thermo stable properties. On the other hand, PI is a hydrophilic polymer, and its dielectric properties largely depend upon absorbed water or humidity. Space charge properties are also affected by humidity or moisture content. In this paper, we studied the effect of water content to the space charge and dc conduction.

\section{Experimental}

The sample was $127 \mu$ m-thick PI film (Kapton 500H). We prepared three types of samples with different water contents, such as dried PI (0 wt.\%), as-received PI (0.9 wt.\%) and water-treated PI (2.9 wt.\%).

The space charge distributions and conduction currents were measured under dc fields up to $50 \mathrm{MV} / \mathrm{m}$ at $333 \mathrm{~K}\left(60^{\circ} \mathrm{C}\right), 313 \mathrm{~K}$ $\left(40^{\circ} \mathrm{C}\right)$ and room temperature. A sample film was mechanichally sandwiched between the grounded Al plate and the semiconductive (SC) layer connected to a high-voltage dc source.

\section{Results and Discussion}

3.1 Space Charge in PI Films When a positive dc voltage was applied to as-received PI films, four kinds of space charges were observed, i.e., positive- and negative-homo space charges in the vicinity of the electrodes and negative- and positive-hetero space charges inside the bulk as shown in Fig. 1. In water-treated PI films, positive- and negative-homo space charges were rapidly formed. In dried PI films, the homo space charges were much reduced and hetero space charges were clearly observed. The homo space charge amounts were the largest in as-received PI films among these samples. When the applied voltage was negative, the space charge distributions were very similer to those charged by positive voltage in each type of samples. The temperature dependence of homo space charge amounts suggested thermally activated charge injection.

3.2 Conductuon Currents The dc conduction currents increased almost exponentially with the water content as shown in Fig. 2. This and space charge phenomena suggest that the absorbed water enhanced not only charge injection from the electrode but also mobility of charge carriers. The field dependence and temperature dependence of charging current in water-treated PI suggest thermally activated conduction such as hopping transport. And the Schottky emission was also suggested for hole injection.

\section{Summary}

Space charge distributions in PI films with different water contents were measured and the effects of electrode materials were discussed. Absorbed water largely enhanced current densities of polyimide films, suggesting that the absorbed water assists not only charge injection from the electrodes but also charge transport in the bulk. The temperature dependence of conduction suggests thermally activated process. The charge injections were not affected by the electrode materials suggesting water-assisted charge injections. Accumulated charge amounts and field distortion are larger in as-received PI than in water-treated PI.

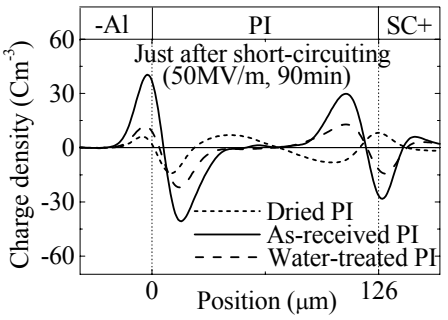

Fig. 1. Space charge distributions in dried, as-received and water-treated PI films at $333 \mathrm{~K}$

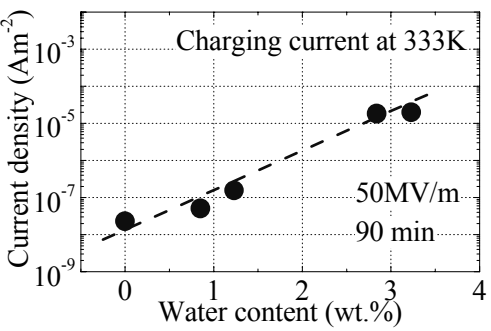

Fig. 2. Charging current with respect to water content 


\section{ポリイミドの空間電荷特性に対する水分の影響}

正員 兼子 一重* 非会員 尾崎 隆志*
学生員 中根 絵美*
正 呈 水谷 照吉**

\section{Effect of Absorbed Water on Space Charge Properties of Polyimide}

Kazue Kaneko*, Member, Takashi Ozaki*, Non-member, Emi Nakane*, Student Member, Yasuo Suzuoki*, Member, Teruyoshi Mizutani**, Member

Space charge distributions in polyimide (PI) films strongly depend upon electric field, temperature, water content and so on. When a dc field was applied to as-received PI films kept in the atmosphere, whose water contents were ca. 0.9 wt. $\%$, four kinds of space charges were observed, i.e., positive- and negative-homo space charges in the vicinity of the electrodes and negativeand positive-hetero space charges inside the bulk. In water-treated PI films, whose water contents were ca. 2.9 wt.\%, positiveand negative-homo space charges were rapidly formed. In dried PI films, the homo space charges were much reduced and hetero space charges were clearly observed. The homo space charge amounts were the largest in as-received PI films among these samples. On the other hand, the dc conduction currents increased almost exponentially with the water content. This suggests that the absorbed water enhanced not only charge injection from the electrode but also mobility of charge carriers. The space charge accumulation and field distortion of PI films are determined by their balance.

キーワード : 空間電荷, ポリイミド, 耐熱性高分子, 含水量, 電導電流

Keywords : space charge, polyimide, high-temperature polymer, water content, conduction current

\section{1. まえがき}

ポリイミド（PI）はその優れた絶縁性能，機械的特性，高 温安定性のため, 高温絶縁材料として広く利用されている。 しかし, 多くの研究者によって検討されているにもかかわ らず，実験結果が測定温度，試料厚さ，電極材料，湿度等 の実験条件によって左右されるため, その電気特性には不 明な点が多く，イオン性伝導 ${ }^{(1) \sim(3)}$, 熱活性型注入(1)(3)(4), thermally assisted tunnelling ${ }^{(5)}$ 等, さまざまな電気伝導モデル が提案されている。他方，PI は親水性であるため，その誘 電特性は吸着された水分や湿度に大きく影響されることが 報告されている(6)(7)。絶縁性能に大きな影響を及ぼす空間電 荷分布も ${ }^{(8)}$, 吸着された水分によって変化すると考えられ る。

\section{本論文では含水量の異なる 3 種類の PI について空間電荷}

\footnotetext{
* 名古屋大学大学院工学研究科電子情報システム専攻 T464-8603 名古屋市千種区不老町 1 Dept. of Electrical Engg. \& Computer Sci., Nagoya Univ., 1 Furo-cho, Chikusa-ku, Nagoya 464-8603

愛知工業大学電気工学専攻

T470-0392 豊田市八草町八千草 1274

Aichi Institute of Technology,

1247 Yachigusa, Yakusa-cho, Toyota 470-0392
}

分布と直流電気伝導特性を測定し, 吸着された水分が PI の 絶縁性能に及ぼす影響について比較検討を行った。

\section{2. 試料および実験条件}

〈2・1〉試料試料として公称厚さ $127 \mu \mathrm{m}$ の東レ・デ ユポン製ポリイミドフィルム（Kapton 500H）を用いた。ま た未処理試料を大気中, $423 \mathrm{~K}\left(150^{\circ} \mathrm{C}\right)$ で 24 時間保持した ものを乾燥試料とし, 純水 (公称 $18 \mathrm{M} \Omega \cdot \mathrm{cm}$ ) に 1 週間浸漬 したものを水処理試料とした。乾燥試料の含水量を $0 \mathrm{wt} . \%$ としたときの未処理試料および水処理試料の平均含 水量はそれぞれ約 $0.9 \mathrm{wt} . \%$ および $2.9 \mathrm{wt} . \%$ であった。含水 量は重量変化により評価した。

〈2·2〉測定条件直流電界印加中および短絡後の空 間電荷分布をパルス静電応力法 (PEA 法)により観測した ${ }^{(9)}$ 。 測定にはファイブラボ製空間電荷測定装置 PEANUTS を用 いた。印加電界は $0 \sim 50 \mathrm{MV} / \mathrm{m}$, 印加時間は 90 分, 短絡 時間は 30 分または 90 分とした。電極は機械的に接触した $\mathrm{Al}$ 板と半導電層 (SC) を用い, $\mathrm{SC}$ 電極に直流高電圧を印加 した (図 1 参照)。以下, 印加電圧が正の場合を正極性, 負 の場合を負極性と呼ぶ。測定温度は $296 \mathrm{~K}\left(23^{\circ} \mathrm{C}\right), 313 \mathrm{~K}$ $\left(40^{\circ} \mathrm{C}\right)$ および $333 \mathrm{~K}\left(60^{\circ} \mathrm{C}\right)$ とした。同様の条件で充電電 


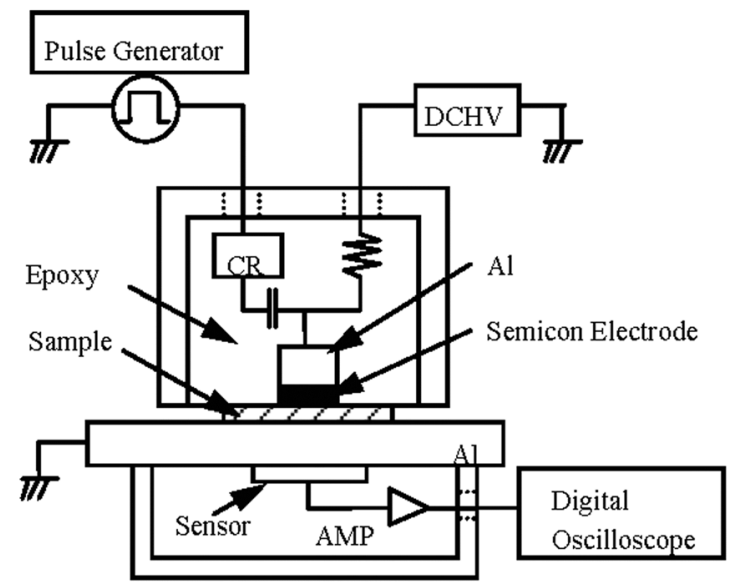

図 1 空間電荷測定装置

Fig. 1. Setup for space charge measurement.

流の測定も行った。

\section{3. 実験結果および検討}

〈3-1〉空間電荷分布の温度依存性 図 2 に未処理試 料の 296 K, $313 \mathrm{~K}$ および $333 \mathrm{~K}$ における空閒電荷分布を示 す。印加電界は正極性 $50 \mathrm{MV} / \mathrm{m}$ とし, 90 分印加後, 短絡し て測定を行った。いずれの温度でも両電極近傍に電極と同 極性の正，負ホモ空間電荷と，バルク内部の陰極側に正， 陽極側に負のへテロ空間電荷の蓄積が見られた。

それぞれの電荷の蓄積量は温度とともに増加した。空間 電荷蓄積量の温度依存性を図 3 に示す。正または負ホモ空 間電荷の蓄積量 $Q$ が電極からの注入量に比例していると仮 定すると，見かけの活性化エネルギ $U$ は

$$
Q \propto \exp \left(-\frac{U}{k T}\right)
$$

より求められる。ここで, $k$ は Boltzmann 定数, $T$ 温度であ る。図 3(a)より, 負および正電荷注入の活性エネルギは, そ れぞれ 0.23 および $0.34 \mathrm{eV}$ と概算された。へテロ空間電荷も また温度とともに増加した（図 3(b)参照）。これらのことは 電荷注入・発生がいずれも熱活性的であることを示唆して いる。ただし，へテロ空間電荷は密度が小さく，隣接する 高密度のホモ空間電荷の信号に打ち消されるため蓄積量の 評価は不正確になり, 詳細な議論はできなかった。

$\langle 3 \cdot 2\rangle$ 空間電荷分布に対する含水量の効果 図 4〜 図 6 にそれぞれ乾燥試料, 未処理試料, 水処理試料の空間 電荷分布の時間変化を示す。測定温度は $333 \mathrm{~K}$, 印加電界は 正極性 $50 \mathrm{MV} / \mathrm{m}$ とした。乾燥試料では電界印加後, 徐々に 正，負へテロ空間電荷および負ホモ空間電荷が形成された (図 4(a)参照)。短絡後は負ホモ空間電荷はやや減衰するが, ヘテロ空間電荷は安定であり, ほとんど減衰しなかった（図 4(b)参照)。未処理試料の場合は電極より注入された電荷の 蓄積により，両電極近傍に顕著な負，正ホモ空間電荷が形 成された。空間電荷分布は電界印加 10 分後にはほぼ安定し た（図 5(a)参照)。この場合，へテロ空間電荷は明確ではな かった。短絡後は正，負電荷とも時間とともに減衰した（図

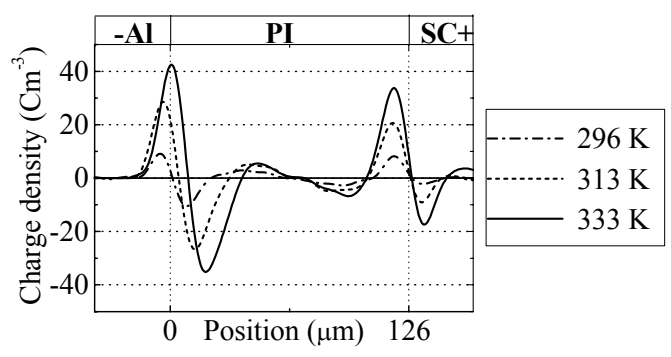

図 2 空間電荷分布の温度による違い $(50 \mathrm{MV} / \mathrm{m}$, 90 分間印加, 短絡直後)

Fig. 2. Space charge distributions at 296, 313 and $333 \mathrm{~K}$ (50 MV/m, $90 \mathrm{~min}$. , after short-circuiting).

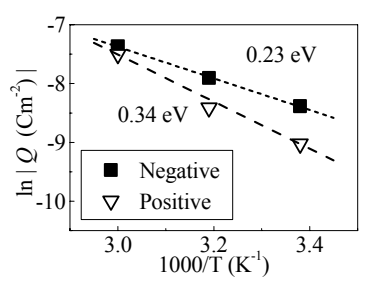

(a) Homo space charges

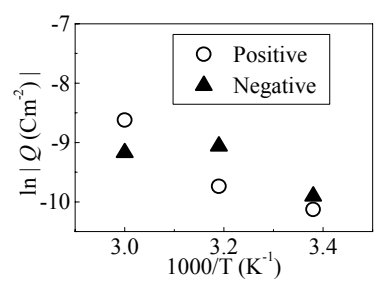

(b) Hetero space charges
図 3 空間電荷量の温度依存性

Fig. 3. Temperature dependences of space charge amounts.

5 (b)参照)。水処理試料の場合も両電極近傍に正, 負ホモ空 間電荷が形成したが，その分布は未処理試料に比べてやや 広がっている。また，その形成速度は非常に速く，電界印 加開始直後に測定した時には空間電荷は既にほとんど飽和 していた（図 6(a)参照)。短絡後の減衰も非常に速く, 空間 電荷は 5 分以内にほぼ消滅した (図 6(b)参照)。

これら 3 種類の試料を比較すると空間電荷蓄積は未処理 試料でもっとも顕著であった。さらに乾燥試料 (図 4) と未 処理試料（図 5) を比較すると, 未処理試料では乾燥試料に 比べて顕著なホモ空間電荷が蓄積しており, PI に吸着され た水分は正, 負電荷の注入を促進することが分かる。また, 未処理試料（図 5）と水処理試料（図 6）を比較すると, 含 水量の増加に伴い, バルク内部での電荷の移動が容易とな ることも明らかとなった。さらに, 乾燥試料, 水処理試料 とも，大気中に放置すると未処理試料とよく似た空閒電荷 特性を示すようになり, 吸水・脱水は可逆的であることが 分かった。

〈3.3〉 電荷注入に対する電極材料の効果 電荷注入 に対する電極材料の効果を調べるため, 負極性 $50 \mathrm{MV} / \mathrm{m}$ を 印加した場合の空間電荷分布も観測した。印加電界を負極 性とした場合，電極材料が異なるにも関わらず，正極性の 場合と同様の空間電荷分布を示した。乾燥試料, 未処理試 料, 水処理試料の空間電荷分布をそれぞれ図 7〜図9に示す。 乾燥試料には正, 負へテロ空間電荷が, 未処理試料, 水処 理試料には負, 正ホモ空間電荷が観測された。ただし, 乾 燥試料については正極性の場合は負ホモ空間電荷が形成さ れたのに対して，負極性の場合は明白なホモ空閒電荷は観 

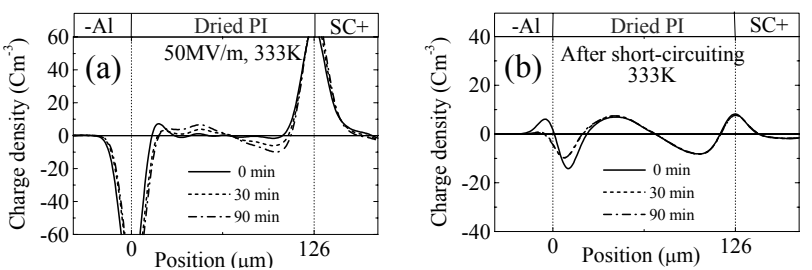

図 4 乾燥試料の空間電荷分布 $(333 \mathrm{~K}$, 正極性 $50 \mathrm{MV} / \mathrm{m}$ )

Fig. 4. Space charge distributions in dried PI films (a) under dc field of $50 \mathrm{MV} / \mathrm{m}$ in positive polarity and (b) after short-circuiting at $333 \mathrm{~K}$.
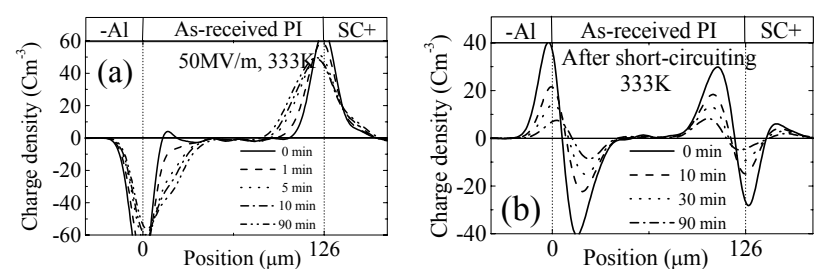

図 5 未処理試料の空間電荷分布 $(333 \mathrm{~K}$, 正極性 $50 \mathrm{MV} / \mathrm{m}$ )

Fig. 5. Space charge distributions in as-received PI films (a) under dc field of $50 \mathrm{MV} / \mathrm{m}$ in positive polarity and (b) after short-circuiting at $333 \mathrm{~K}$.
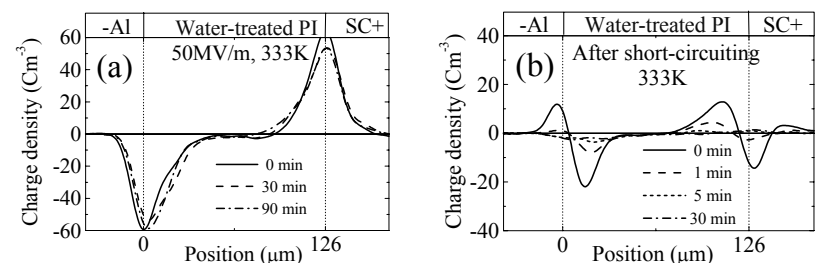

図 6 水処理試料の空間電荷分布 $(333 \mathrm{~K}$, 正極性 $50 \mathrm{MV} / \mathrm{m}$ )

Fig. 6. Space charge distributions in water-treated PI films (a) under dc field of $50 \mathrm{MV} / \mathrm{m}$ in positive polarity and (b) after short-circuiting at $333 \mathrm{~K}$.

測されなかった。即ち，多少とも水分が吸着している場合 には電極材料の効果はなく, 電荷注入に対して水分が重要 な役割を果たしていることが確認できた。

\section{〈3.4〉＼cjkstart空間電荷の蓄積量の電界依存性ＰI における} 空間電荷分布形状は印加電界を変化させてもほとんど変化 せず，蓄積電荷量のみが変化した ${ }^{(10)}$ 。そこで，全ての試料 で観測された負ホモ空間電荷に着目し，333 K における短絡 直後の蓄積電荷量と電界の関係を図 10 に示した（正極性）。 蓄積電荷量はどの電界でも未処理試料が最も多く, 乾燥試 料が最も少なかった。また未処理試料では電界の増加に伴 つて蓄積電荷量が増大寸るが，水処理試料では蓄積電荷量 は $20 \mathrm{MV} / \mathrm{m}$ 以上で飽和した。水処理試料では未処理試料よ りホモ空間電荷の形成・隇衰が速いことから（図 5, 図 6 参 照), 吸着水分によってキャリアの移動が容易になり, 対向 電極まで進展し, 見かけの電荷密度が小さくなったためと 考えられる。

$\langle 3 \cdot 5\rangle$ 充電電流に対する含水量の効果 図 $11(\mathrm{a})$ に
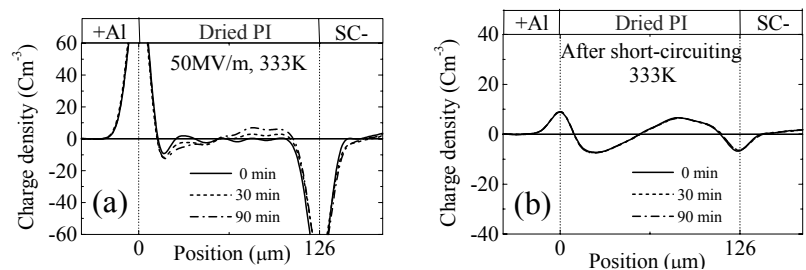

図 7 乾燥試料の空間電荷分布 (333 K, 負極性 $50 \mathrm{MV} / \mathrm{m}$ )

Fig. 7. Space charge distributions in dried PI films (a) under dc field of $50 \mathrm{MV} / \mathrm{m}$ in negative polarity and (b) after short-circuiting at $333 \mathrm{~K}$.
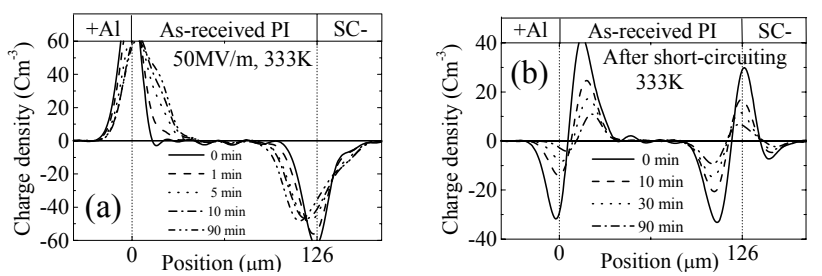

図 8 未処理試料の空間電荷分布 $(333 \mathrm{~K}$, 負極性 $50 \mathrm{MV} / \mathrm{m})$

Fig. 8. Space charge distributions in as-received PI films (a) under dc field of $50 \mathrm{MV} / \mathrm{m}$ in negative polarity and (b) after short-circuiting at $333 \mathrm{~K}$.
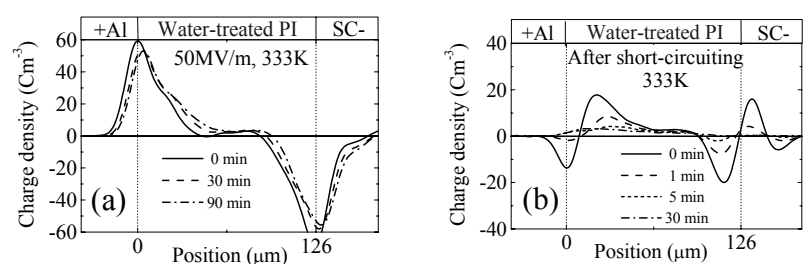

図 9 水処理試料の空間電荷分布 $(333 \mathrm{~K}$, 負極性 $50 \mathrm{MV} / \mathrm{m})$

Fig. 9. Space charge distributions in water-treated PI films

(a) under dc field of $50 \mathrm{MV} / \mathrm{m}$ in negative polarity and (b) after short-circuiting at $333 \mathrm{~K}$.

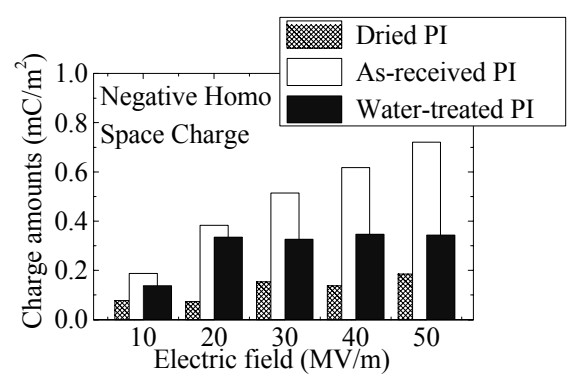

図 10 負ホモ空間電荷量の電界依存性（333 K，正極性）

Fig. 10. Field dependence of negative homo space charge amounts at $333 \mathrm{~K}$ in positive polarity.

$333 \mathrm{~K}$ における 3 種類の試料の充電電流の過渡特性を示す。 印加電界は正極性 $50 \mathrm{MV} / \mathrm{m}$ とした。PI の充電電流密度は含 水量に大きく依存し, 水処理試料では電流密度は乾燥試料, 未処理試料より二桁以上大きくなった。充電電流密度の含 水量に対する依存性はほとんど指数関数的であった（図 

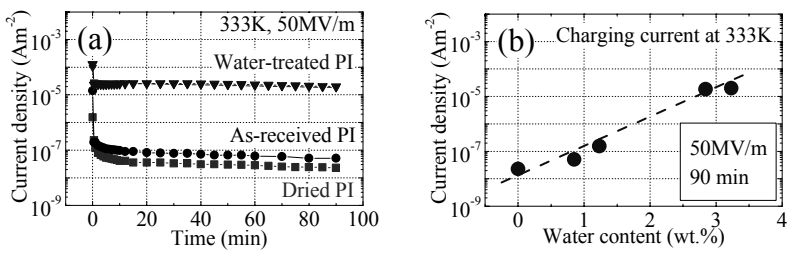

図 11 含水量の異なる PI の充電電流密度 : (a) $J-t$ 特性, (b) 含水量依存性 $(333 \mathrm{~K}$, 正極性 $50 \mathrm{MV} / \mathrm{m})$

Fig. 11. Charging current of PI films with various water content; (a) transient current and (b) dependence upon water content.
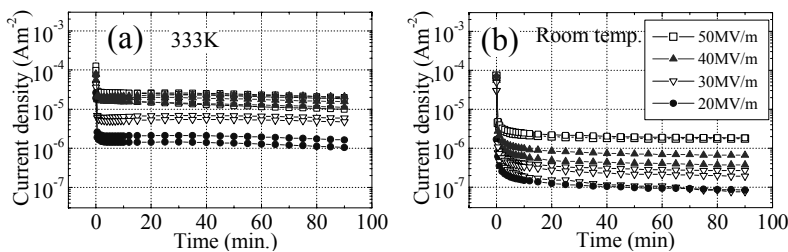

図 12 水処理試料の電流密度の過渡特性（正極性）;
(a) $333 \mathrm{~K}$ および
(b) 室温 ;
$50 \mathrm{MV} / \mathrm{m}$

- $40 \mathrm{MV} / \mathrm{m}, \nabla 30 \mathrm{MV} / \mathrm{m}, 20 \mathrm{MV} / \mathrm{m}$

Fig. 12. Transient current of water-treated PI under various fields of positive polarity at (a) $333 \mathrm{~K}$ and (b) room temperature.

11(b)参照)。充電電流の顕著な含水量依存性は, PI に吸着さ れた水分がバルク中でのキャリア移動を促進すると同時に 電極からの電荷注入も増加させることを示唆している。

$\langle 3.6\rangle$ 水処理試料の充電電流特性 水処理試料の $333 \mathrm{~K}$ および室温における充電電流の $J-t$ 特性（正極性）を 図 12(a)および図 12(b)に示す。充電電流密度は温度とともに 増加し, 水処理試料でも未処理試料同様, 電荷注入あるい は電荷輸送が熱活性型であることを示唆している。

水処理試料の充電電流密度の印加平均電界依存性に高電 界のホッピングモデルの式

$$
J=\text { enavexp }\left(-\frac{U}{k T}\right) \exp \left(\frac{e a E}{2 k T}\right)
$$

を適用すると, みかけのホッピング距離 $a$ は $333 \mathrm{~K}$ では $5.1 \mathrm{~nm}$, 室温では $5.0 \mathrm{~nm}$ と評価された（図 13 参照）。障壁高 さUは $0.61 〜 0.63 \mathrm{eV}$ であった。ただし, $e$ は素電荷, $n$ 電 荷数密度, $v$ 試行頻度, $E$ 印加平均電界である。得られたホ ッピング距離は実験条件の異なる Sharma らの結果 ${ }^{(3)}$ と近 い值となったが, 含水量より評価された吸着水の平均分子 間距離 $0.9 \mathrm{~nm}$ よりかなり大きくなった。すべての水分子が クラスタを形成していると仮定すると 180 分子で 1 クラス

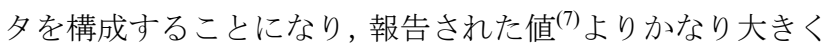
なった。したがって, PI の伝導は含水量に大きく依存する が，吸着した水分子が直接ホッピングサイトとして機能す るとは考えにくい。

さらに, 充電電流密度を印加平均電界, 陽極電界, 陰極

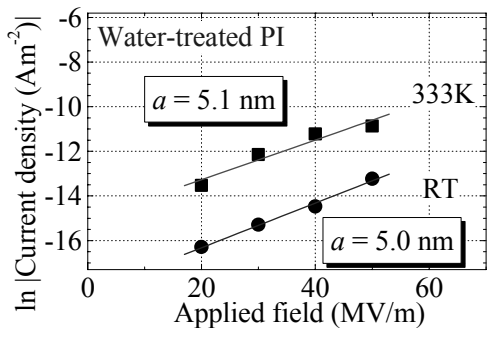

図 13 水処理試料の充電電流密度の電界依存性 (正極性)

Fig. 13. Field dependence of charging current densities at $333 \mathrm{~K}$ and room temperature.

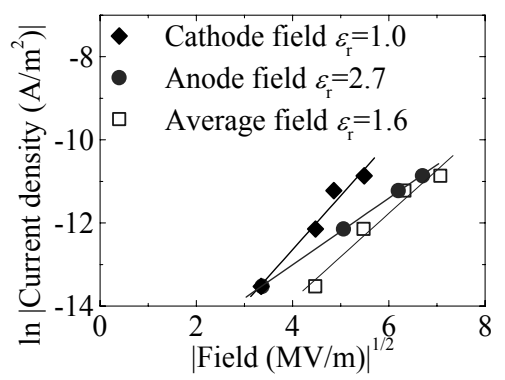

図 14 充電電流密度の印加平均電界 $(\square), \mathrm{Al}$ 陰極電界 および SC 陽極電界（○）依存性（333 K, 正極性）

Fig. 14. Schottky plots of charging currents with respect to the applied average field, $\mathrm{SC}$ anode field and $\mathrm{Al}$ cathode field in positive polarity at $333 \mathrm{~K}$.

電界を用いて Schottky プロットすると, 比誘電率 $\varepsilon_{r}$ はそれ ぞれ，1.6，2.7，1.0 となった（図 14 参照)。陽極電界から 評価された比誘電率は PI の比誘電率 3.4 に近い值であり, 陽極からの正孔注入が Schottky 効果によることが示唆され る。すなわち, 陽極近傍では正電荷のみが伝導電流に寄与 することを示唆している。水処理試料の空間電荷形成過程 を詳細に見ると（図 6(a)または図 9(a)），電界印加後，正， 負空間電荷は徐々に試料内部に進展するが, 正電荷の進展 が優勢であり， 30 分以降は, 負空間電荷はやや陰極側に若 干押し戻されたように見える。また，短絡直後の空間電荷 を見ても（図 9(b)），正の空間電荷は試料内部まで進展して いる。したがって, 両電極から注入した正, 負電荷はバル ク内部で相殺し, 少なくとも陽極近傍では伝導電流に寄与 するのは正電荷のみと考えることができる。なお, 電極近 傍では顕著な空間電荷蓄積によって電界分布が大きく変化 するため単純に Schottky 効果を適用することには問題があ るが，一様電界下では電極からポテンシャルの極大までの 距離は $50 \mathrm{MV} / \mathrm{m}$ の場合は $1.5 \mathrm{~nm}, 10 \mathrm{MV} / \mathrm{m}$ でも $3.3 \mathrm{~nm}$ であ り, このような短距離では空間電荷による電界の変化は余 り大きくないこと, 電極電界の評価自体にかなりの誤差が 含まれること，などからその点は無視できるものと考えた。

\section{4. まとめ}

親水性の耐熱性高分子であるポリイミド（PI）について， 
吸着された水分が PI の絶縁性能に及ぼす影響を明らかにす るため, 含水量の異なる 3 種類の PI について空間電荷分布 と充電電流を測定し，比較検討を行った。

これらの試料に直流電界を印加すると，未処理試料では 電極近傍に負, 正ホモ空間電荷とバルク内部に正, 負へテ ロ空間電荷の 4 種類の空間電荷が観測された。乾燥試料で は, 電極近傍のホモ空間電荷は非常に小さくなり, 主とし て正, 負ヘテロ空間電荷が観測された。逆に水処理試料で は主として正，負ホモ空間電荷が観測された。ホモ空間電 荷の形成は含水量が多いほうが速く, 伝導電流は含水量の 増加に伴って急激に増加した。これらのことから, PI に吸 着した水分は電極からの電荷注入を促進するばかりでな く, 電荷キャリアのみかけの移動度を大きくすることが明 らかとなった。また, 電極からの正, 負電荷注入が熱活性 的であること, 水処理試料では SC 電極からの正電荷注入は Schottky 効果によること, 試料内部での電荷輸送が熱活性的 であることも示唆された。

本研究により, PI の電気伝導特性が吸着した水分によっ て変化すること, 特に大気中に放置した PI に顕著な空間電 荷蓄積が見られることなど，絶縁材料としての利用に対す る環境の影響について重要な知見が得られた。これらの実 験結果をもとに電荷の注入と輸送のメカニズムと水分の影 響についても検討する予定である。

(平成 17 年 11 月 11 日受付, 平成 18 年 7 月 14 日再受付)

\section{文献}

(1) E. Sacher : "Dielectric properties of polyimide film. II. DC properties", IEEE Trans. Elect. Insul., Vol.EI-14, No., pp.85-93 (1979)

(2) G. Sawa, S. Nakamura, K. Iida, and M. Ieda : "Electrical conduction of polypromellitimide films at temperatures of $120-180^{\circ} \mathrm{C}$ ", Jpn. J. Appl. Phys., Vol.19, pp.453-458 (1980)

(3) B. L. Sharma and P. K. C. Pillai : "Electrical conduction in Kapton polyimide film at high electric fields", Polymer, Vol.23, pp.17-20 (1982)

(4) G. M. Sessler, B. Hahn, and D. Y. Yoon : "Electrical conduction in polyimide films", J. Appl. Phys., Vol.60, pp.318-326 (1986)

(5) J. R. Hanscomb and J. H. Calderwood : "Thermally assisted tunnelling in polyimide film under steady-state and transient conditions", J. Phys. D: App. Phys., Vol.6, pp.1093-1104 (1973)

(6) B. S. Lim, A. S. Nowick, K.-W. Lee, and A. Viehbeck : "Sorption of water and organic solutes in polyimide films and its effects on dielectric properties", J. Polym. Sci.: Pt. B: Polym. Phys., Vol.31, pp.545-555 (1993)

(7) G. Wu, C. C. Gryte, A. S. Nowick, S. Z. Li, Y. S. Pak, and S. G. Greenbaum : "Dielectric relaxation and deuteron NMR of water in polyimide films", J. Appl. Phys., Vol.66, pp.5290-5296 (1989)

(8) K. Fukunaga and T. Maeno : "Measurement of space charge distribution in polyimide film", T. IEE Japan, Vol.114-A, pp.560-561 (1994-7/8) (in Japanese)

福永 香・前野 恭：「ポリイミドフィルムの空間電荷蓄積現象の 観察」, 電学論 A, 114, 7/8, pp.560-561 (1994)

(9) T. Maeno, T. Futami, H. Kushida, T. Takada, and C. M. Cooke : "Measurement of spatial charge distribution in thick dielectrics using the pulsed electroacoustic method", IEEE Trans. Elect. Insul., Vol.23, pp.433-439 (1988)

(10) K. Kaneko, T. Ozaki, E. Nakane, and T. Mizutani : "Space charge phenomena in polyimide films and effects of absorbed water", Proc. 2005 Int. Symp. Electri. Insul. Mat., pp.65-68, Kitakyushu (2005-6)

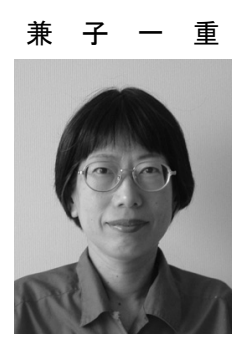

（正員） 1974 年 3 月奈良女子大学卒業。1974 年 4 月より名古屋大学工学部技術補佐員, 教務 職員を経て 1995 年 4 月助手, 現在に至る。計 算機シミュレーションによる有機高分子の電 気物性に関寸る研究に従事。IEEE, 日本物理学 会会員。

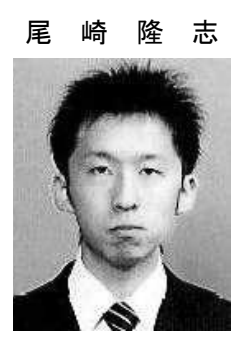

(非会員) 2001 年 4 月名古屋大学入学, 2005 年 3 月名古屋大学卒業。同年 4 月静岡市役所勤 務,現在に至る。在学中は各種高分子絶縁材料の 空間電荷特性に関する研究に従事。

中 根 絵 美

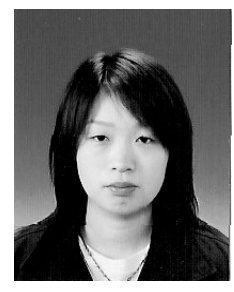

鈴 置 保 雄

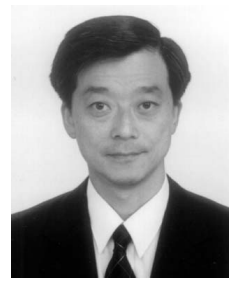

学会会員。

水 谷 照 吉 (正員) 1969 年 3 月名古屋大学大学院工学研

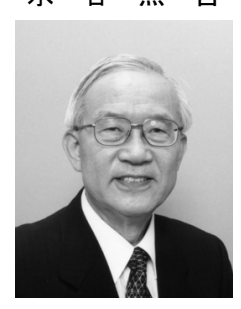
究科博士課程満了。同年 4 月より名古屋大学工 学部電気学科助手, 講師, 助教授を経て 1987 年 7 月同教授, 2005 年 3 月同定年退職。名古屋 大学名誉教授, 愛知工業大学/信州大学客員教 授, （社）電線総合技術センター会長, 現在に 至る。工学博士。1997 年電気学会業績賞受賞。 主として誘電・絶縁材料, 薄膜デバイス, 有機 エレクトロニクスに関する研究に従事。IEEE Fellow, 忘用物理学会, 高分子学会, 放電学会, 素材物性学会, CIGRE 会員。 